\title{
Biblioteca Nacional De Brasília: do pesadelo ao sonho
}

Antonio Miranda*

Brasília esperou mais de quatro décadas para ter a sua Biblioteca Nacional construída. Criada por decreto do Primeiro Ministro Tancredo Neves em 1962, junto ao Ministério da Educação e Cultura, determinando que duplicatas da Biblioteca Nacional do Rio de Janeiro fossem transferidas para a sua instalação. A crise política do período deve ter impedido a sua concretização.

Há quem considere impróprio a Capital Federal do Brasil ter uma biblioteca nacional. A Alemanha tem mais de uma, a Itália - cuja unificação tardia das diversas regiões só aconteceu no século XIX - tem várias. Os Estados Unidos da América, nenhuma. Aliás, tem bibliotecas nacionais especializadas em agricultura, medicina e educação. Quem faz as vezes de biblioteca nacional é a Library of Congress. O Brasil tem duas bibliotecas legislativas nas duas casas do Congresso Nacional. Ou seja, cada país institui seu sistema bibliotecário e de informação conforme regras próprias e não há um modelo a seguir.

O primeiro projeto arquitetônico foi de nosso grande arquiteto Oscar Niemeyer no final da década de 80 do século passado e um seminário promovido (em outubro de 1988) discutiu à exaustão as questões pertinentes e fez recomendações a serem consideradas tanto na construção do prédio quanto na organização dos acervos e serviços da nova biblioteca. Infelizmente, não foi possível a construção naqueles anos de superinflação e de dívida externa elevada. Embora não faltassem recursos para a construção de estádios de futebol.

Um novo projeto surgiu em 2004, no governo passado, depois de Brasília tornar-se Patrimônio Cultural da Humanidade. O Projeto Monumenta da Unesco promoveu um seminário numa cidade dos arredores do DF para discutir e aprovar a iniciativa, organizado pelas secretarias de cultura e de obras do GDF. Participante do evento, insistimos para que ficasse uma recomendação no sentido de se criar um grupo de trabalho com os objetivos urgentes de definir o perfil e os serviços da nova biblioteca. Deveria orientar o detalhamento do projeto arquitetônico e dar início a uma força-tarefa para começar a organizar os acervos e

serviços a serem transladados para o edifício na época de sua inauguração. Nada disso aconteceu. Em seminário promovido pela Associação dos Bibliotecários do Distrito Federal no Congresso Nacional, pouco tempo depois, a discussão reacendeu e até ganhou espaço na imprensa e na internet, mas nem assim foram tomadas as providências sugeridas. As inaugurações no final de 2006 revelaram um edifício vazio.

Seis meses depois, a população espera pela abertura definitiva, mas ainda existem pendências para a recepção definitiva da obra e sua abertura ao público. Nas condições atuais, não é possível instalar acervos e serviços. Não há porque esconder a verdade, em respeito ao direito à informação. Qual o pesadelo? O sol invade os salões da biblioteca o tempo todo e impede que se instalem estantes e mesas para leitura, assim também computadores e outros equipamentos. Discute-se se houve mudança no projeto original que previa combogós ou grade mais fechada do que a efetivamente instalada, para impedir o excesso de luz solar e diminuir o calor. Com o agravante de ampliar o custo com ar condicionado. Além de problemas de segurança, vazamentos, e da ausência de escadas e rampas para os leitores, obrigando-os ao uso exclusivo de elevadores, estacionamento sub-dimensionado, entre outros

\footnotetext{
* Professor da Universidade de Brasília, Doutor em Ciência da Informação e membro da Comissão Especial do Conjunto Cultural da República.
} 
problemas. Faltou ao projeto as orientações que cobrávamos anos antes... Nada a ver com a concepção de Niemeyer, mas com o detalhamento de espaços que não tiveram as informações adequadas.

Todos os problemas apontados podem ser resolvidos ou minimizados. Com o apoio de uma arquiteta, fizemos um levantamento minucioso dos pontos críticos e, um a um, estão sendo analisados, e as propostas de solução encaminhadas para as instâncias competentes. Leva algum tempo para serem implementadas, requerem recursos que, à ausência de um orçamento previsto para este ano, depende de verbas excepcionais. Estão sendo levantadas as especificidades técnicas e os preços para a abertura de editais para compra de materiais como filtros de luz, correção de rampas para portadores de deficiências físicas, colocação de portas de vidros, etc., quando não for de responsabilidade da construtora.

Não obstante, medidas paralelas vêm sendo tomadas no sentido de organizar a biblioteca. A Comissão Especial do Conjunto Cultural da República, criada pelo Governo do GDF, com membros representantes dos ministérios da Educação, Cultura, Ciência e Tecnologia, Universidade de Brasília, e da própria Secretaria de Cultura do DF já redigiu o documento final sobre o perfil e as diretrizes básicas para a BNB (Biblioteca Nacional de Brasília) e logo estará sendo discutida em audiência pública. Um centro de inclusão digital já está sendo montado no andar térreo, com recursos do MCT e da iniciativa privada, e parte dele foi inaugurado recentemente com uma videoconferência com a participação de crianças do Brasil e de Portugal. Vai capacitar estudantes, desempregados, aposentados e o público em geral, a partir de grupos selecionados em todas as regiões administrativas do DF, para garantir um efeito multiplicador nas escolas, centros comunitários e pontos de inclusão já instalados, para difundir as melhores práticas. Inicia-se com a capacitação do pessoal de segurança, de limpeza que trabalha na região da BNB. Exposições e eventos vêm acontecendo em salas e no auditório há mais de três meses, com significativa frequiência de público.

Contatos com editoras universitárias, de institutos de pesquisa e da indústria editorial vão garantir doações importantes que já estão chegando ou devem chegar quando os espaços próprios estiverem habilitados. Uma biblioteca virtual está sendo planejada para disseminar acervos próprios e de outras instituições, depois da inauguração da infra-estrutura da web 2 que está sendo instalada pela Rede Nacional de Pesquisa, prevista pra o final de julho. Deve garantir acesso a usuários de todo o país e do exterior, vinte e quatro horas por dia.

Com recursos do MCT estão sendo montados, além das salas de alfabetização digital já mencionados, uma midiateca e um laboratório de mídia digital, os recursos de rede e a instalação de painéis virtuais de um projeto de Marcello Dantas, nos mesmos moldes do Museu da Língua Portuguesa (que ele montou na Estação da Luz de São Paulo). Deverá constituir-se em atração para familiarizar o público com as novas tecnologias digitais que vão ser popularizadas com a implantação definitiva da TV digital em nosso país.

Cabe ainda ressaltar a disposição do governo local de ceder os espaços do antigo Touring Clube do Brasil, vencidas as pendências em fase de negociação, para instalar ali um centro cultural e uma sala de leitura livre, com segurança e conforto, aproveitando a proximidade com o sistema de transporte (metrô, rodoviária) e das atividades comerciais e culturais de seu entorno. A reabertura da passagem de nível entre o Conic e o Conjunto Cultural da República vai permitir o fluxo livre de pedestres que hoje é penalizado ao ter que fazer trajetos incômodos e inseguros. Será possível criar um corredor cultural entre o Teatro Dulcina (já em fase de tombamento), a biblioteca e o museu, assim também com o Teatro Nacional e outros aparelhamentos de diversão e lazer da região. A revitalização da área poderá talvez atrair quiosques para livrarias e sebos, e outras atividades que promovam emprego e renda. Um sonho. O importante é que estas propostas, uma vez definitivamente aprovadas, sejam definitivamente implementas. 
Podemos tentar a criação de um consórcio intergovernamental, com órgãos da administração federal - MEC, MCT, MinC, da UnB e da iniciativa privada para garantir uma gestão colegiada e o compartilhamento de investimentos e recursos. A legislação permite e há bons exemplos em gestação. Uma tendência que orienta a institucionalização de serviços públicos que evitem excessos burocráticos, para se tornarem mais livres de ingerências políticas e partidárias, serem mais autônomos, estáveis e menos sujeitos às descontinuidades administrativas que comprometem a eficiência e a eficácia de alguns órgãos de governo. A audiência pública certamente vai aportar sugestões e críticas construtivas para que a proposta seja a mais realista possível e atenda as expectativas da população.

Uma biblioteca do século XX, com visão sistêmica. e considerando a complexidade das redes de informação, deverá ser híbrida. Não poderá mais conformar-se nos moldes de bibliotecas tradicionais, ou seja, deverá considerar públicos diversificados, em diferentes níveis, compreendendo serviços que antes estavam sendo oferecidos por diferentes tipos de bibliotecas - escolares, públicas, universitárias, especializadas. As novas tecnologias permitem o uso e reuso de informações segmentadas, orientadas para públicos internos e externos de forma mais ampla e democrática do que antes. Em verdade, o que vemos hoje é que os serviços bibliotecários são estanques e privilegiam as camadas superiores da população. A perversidade está em que a prestação de serviços acompanha a distribuição de renda, ou seja, as elites dispõem de bibliotecas universitárias e especializadas em condições razoáveis enquanto os mais pobres disputam os espaços limitados e os acervos insuficientes e não raras vezes desatualizados de bibliotecas escolares e públicas. A experiência brasileira demonstra a falência desses tipos de bibliotecas - as poucas bibliotecas públicas fazendo as vezes das escolares, que raramente existem. Em quadro tão dramático e perverso, não há mais lugar para modelos "puros" de bibliotecas. Daí porque optamos por instituir uma biblioteca nacional com atribuições de biblioteca pública e escolar, com um programa de alfabetização digital e de promoção do hábito de leitura. As novas tecnologias podem facilitar esta segmentação e diversificação, permitindo o uso massivo de acervos físicos e virtuais ao mesmo tempo em que se preserve acervos valiosos e atenda pesquisadores e cientistas. Por que não? 